\title{
Effect of Storage on Quality Characteristics of Sterilized Mango Based Dairy Beverage
}

\author{
Preeti Shukla $^{1 *}$, U. Bajwa ${ }^{1}$ and Suresh Bhise ${ }^{2}$ \\ ${ }^{1}$ Department of Food Science and Technology, Punjab Agricultural University, Ludhiana, \\ Punjab, India \\ ${ }^{2}$ College of Horticulture, Anand Agricultural University, Anand, Gujarat, India \\ *Corresponding author
}

\begin{tabular}{|l|}
\hline K e y w or d s \\
Milk beverage, \\
Functional, \\
Sterilized, \\
Antioxidant activity \\
\hline Article Info \\
\hline $\begin{array}{l}\text { Accepted: } \\
\text { 10 March } 2018 \\
\text { Available Online: } \\
\text { 10 April } 2018\end{array}$ \\
\hline
\end{tabular}

\section{Introduction}

A functional food can be: an unmodified natural food; a food in which a component has been enhanced through special growing conditions, breeding, or biotechnological means; a food to which a component has been added to provide benefits; a food from which a component has been removed by
A study was undertaken to assess the effect storage on the quality of functional dairy beverage prepared using milk, sugar and adding 30\% mango pulp. The drinks were sterilized and stored at ambient temperature for determining their shelf life. A significant ( $p<0.01)$ loss of ascorbic acid and reducing sugar content of the drinks occurred during storage for 75 days. Changes antioxidant activity and HMF content indicated decreased functionality and deterioration in appearance and flavor scores of the drinks. It was found that sterilized functional beverage was acceptable up to 60 days. Standard plate count, yeast and molds and spore formers were not detected throughout the storage of beverage. Based on consumer demand and the potential health benefits, we believe that new functional beverages will be launched. The keys to design new functional beverages could be: addition of a component to provide health benefits; removal of a component by technological or biotechnological means so that the food provides benefits not otherwise available; replacement of a component by an alternative component with favorable properties; modification of a component by enzymatic, chemical, or technological means to provide a benefit or a combination of any of the above The future of functional beverages depends on the unequivocal demonstration of their efficacy in promoting health. Thus, a joint venture between food producers and researchers is advisable, as a tool to provide scientific evidence of many health claims, as well as a way to find successful strategies to improve the appeal of functional beverages. 
combination of any of the above (Pravst, 2012). The global functional beverages market drives due to the growth in health and wellness concerns, consumer awareness, increase in disposable incomes obesity concerns, aging population, introduction of new flavoured products meeting various nutritional and health requirements and changing lifestyles (Yadav et al., 2010).

Food proteins, especially milk caseins, may act as a precursor of biologically active peptides with different physiological effects (Ozer and Kirmaci, 2010). Maillard reaction products generated from sugar-protein model in food materials during processing and storage have strong antioxidant activity (Rao et al., 2011). The antioxidant activity of MRPs was first reported by Franzke and Iwainsky (1954). The higher interaction between lactose and proteins in milk having higher $\mathrm{pH}$ value could lead to more Maillard Reaction Products (MRP) as well as more polymerisation of proteins (Gothwal and Bhavadasan, 1992). As a result, the sensory, safety, nutritional and health-promoting attributes of the foods are enhanced (Ames, 2009). Some fractions of MRPs were reported to have strong antioxidant properties comparable to those of commonly used food antioxidants (Lingnert and Hall, 1986).

Mango pulp and milk can be utilized to make the product therapeutic, prophylactic and nutritionally rich which may increase its demand in food and beverage industry. Mango (Mangifera indica L.) is one of the favored fruits in the tropical and sub-tropical regions. It has an excellent flavor, attractive fragrance, delicious taste and high nutritional value that have made it one of the best fruits (Pal, 1998).

The antioxidants work synergistically and the most common antioxidant combination is the use of vitamins A, C, and E. They are the most highly utilized nutrients in bruit based milk beverages aimed at targeting free radicals in the body and could equally be the most recognized by consumers. The main goal of antioxidants is to fight free radicals which are believed to be responsible and linked to many leading diseases in the world. Antioxidants may be utilized in beverages to enhance their functionality by boosting the immunity, improving blood, circulation and sharpening mental acuity.

Keeping these points in mind, the present study was planned with the objectives to develop a sterilized functional beverage using milk and mango with high antioxidative properties and to study the shelf life of beverage and assess the effect of storage on the quality characteristics and sensory properties of functional dairy beverage.

\section{Materials and Methods}

\section{Raw materials}

\section{Milk}

It was procured from College of Dairy Science and Technology, Guru Angad Dev Veterinary and Animal Sciences University (GADVASU).

\section{Sucrose}

It was purchased from local market of Ludhiana, Punjab.

\section{Whey protein concentrates $(70 \%)$}

It was supplied by Mahaan proteins, New Delhi,

\section{Casein}

Soluble casein $(99.9 \%)$ was made available by SD fine chemicals. DPPH was obtained from Sigma Aldrich, USA. 
Proximate composition of milk and mango pulp

\section{Physico-chemical analyses}

Milk, mango pulp and prepared milk drinks were analyzed for physico-chemical parameters using AOAC (2000) procedures. For each parameter, the samples were analysed in three replications.

\section{Total soluble solids}

TSS of milk drink samples was determined at $20{ }^{\circ} \mathrm{C}$ using Hand Refractometer (Erma, Japan).

\section{pH}

The $\mathrm{pH}$ of all the samples was determined using pocket $\mathrm{pH}$ meter (Model IQ 125, IQ Scientific, USA).

\section{Titratable acidity}

The titratable acidity of milk and milk drinks was determined by titrating $10 \mathrm{ml}$ of sample against $0.1 \mathrm{~N} \mathrm{NaOH}$ and expressed as \% lactic acid.

\section{Reducing and total sugars}

Lane and Eynon method of Ranganna (1994) was used for determining reducing sugars in milk drink samples. The method was slightly modified for the determination of total sugars.

\section{Viscosity}

Dynamic viscosity in centipoise $(\mathrm{cP})$ of all the milk drinks was measured using the Hoppler Viscosimeter (design type $\mathrm{BH} 2$, Surrey, England) at $20^{\circ} \mathrm{C}$. The time of fall of a ball (No.1) in a cylindrical tube (internal diameter $=15.94 \mathrm{~mm}$ ) inclined by $10^{\circ}$ with respect to the vertical plane and filled with the liquid to be examined, was measured. The time taken by the ball to travel a distance of $100 \mathrm{~mm}$ was recorded. The dynamic viscosity was calculated as per Mittal and Bajwa (2011).

\section{Ascorbic acid}

It was estimated using the titrimetric method as described by Ranganna (1994) using 2, 6dichlorophenol-indophenol dye was followed.

Preparation of mango flavoured milk beverage

The process of preparation of mango flavoured milk beverage is presented in Fig 1. RSM was used to optimize the level of ingredients. It was found that 0.5 per cent milk fat $(\mathrm{v} / \mathrm{v}), 6.0$ per cent sugar $(\mathrm{w} / \mathrm{v})$ and 30.0 per cent mango pulp yielded the beverage with maximum antioxidant activity and highest acceptability.

Hence, these levels were used for further studies. The drinks were heated to $65^{\circ} \mathrm{C}$ with constant stirring, filtered through a muslin cloth to remove fibres, if any, homogenized at $2000 \mathrm{psi}$, filled in HDPE packaging material $(200 \mathrm{ml})$ or sterilized glass bottles $(200 \mathrm{ml})$, sealed, labeled and sterilized at $116{ }^{\circ} \mathrm{C}$ for 15 min and cooled to $5.0^{\circ} \mathrm{C}$. These bottles were stored at $25.0 \pm 0.1{ }^{\circ} \mathrm{C}$.

\section{Storage studies}

The stored samples were evaluated for physico-chemical changes and sensory attributes at regular time intervals.

The pasteurized samples were subjected to analyses at an interval of two days whereas the sterilized ones were evaluated after 15 days. The samples stored at room temperature were also chilled before subjecting to organoleptic evaluation. 


\section{Antioxidant activity}

Antioxidant activity was estimated using standard procedure of DPPH (2, 2-diphenyl1picrylhydrazyl) assay (Tepe et al., 2005). Six $\mathrm{ml}$ of DPPH solution $(0.2 \mathrm{mM}$ in $80 \%$ methanol) was mixed with $2.0 \mathrm{ml}$ of each sample. The samples were incubated for 30 min in dark at room temperature $\left(25 \pm 2{ }^{\circ} \mathrm{C}\right)$. The absorbance (A) was measured at $518 \mathrm{~nm}$ by using Spectronic-20 (Bausch and Lomb, USA) Spectrophotometer. The percentage of the radical scavenging activity was calculated as percentage inhibition of DPPH radicals using the following equation:

$\mathrm{DPPH}=\frac{\text { gh inhibition of }[\mathrm{A} \text { control }-\mathrm{A} \text { sample] } \mathrm{x} 100}{A \text { control }}$

Where, $\mathrm{A}$ is Absorbance

Two $\mathrm{ml}$ methanol (80\%) plus $6.0 \mathrm{ml}$ distilled water was used as a blank. For the control, DPPH solution replaced distilled water.

\section{HMF estimation}

HMF was estimated using the procedure of Morales et al., (1997), with slight modification. Twenty $\mathrm{ml}$ samples of wellmixed milk ingredients were subjected to different heat treatments and cooled rapidly in ice bath.

Thereafter samples were slowly deproteinized with $10 \mathrm{~mL}$ of trichloroacetic acid solution (TCA) $(10 \%, \mathrm{w} / \mathrm{v})$, centrifuged and filtered through Whattman No.42 filter paper. Ten ml filtrate was taken in separating funnel and extracted with $20 \mathrm{ml}$ ether thrice. The extracts were combined and again filtered through Whattman No.1 filter paper.

To $3 \mathrm{ml}$ filtrate, add $3 \mathrm{ml}$ ethanol (99.99\%) and $1 \%$ resorcinol in $\mathrm{HCl}$. It was mixed well and stored in dark for $30 \mathrm{~min}$ at ambient temperature $\left(25 \pm 1^{\circ} \mathrm{C}\right)$ for the development of reddish pink color. The absorbance was measured at $540 \mathrm{~nm}$ using Spectronic-20 spectrophotometer.

The concentrations of HMF in the samples were calculated from standard curve of HMF prepared using concentrations ranging from 0 to $180 \mathrm{mg} / \mathrm{ml}$. The amount of HMF was obtained as $\mathrm{mg} / 100 \mathrm{~g}$ using the formula:

$\mathrm{HMF} \quad(\mathrm{mg} / 100 \mathrm{~g})$
$\frac{\text { Conc.from standard curve } \mathrm{x} \text { Dilution factor }}{\text { Volume taken for color development } \mathrm{x} \text { Sample wt }(\mathrm{gm})}$

\section{Microbiological studies}

Standard plate count (SPC), yeast and mould count (YMC) and psychrophillic counts were recorded as per APHA (1984) procedures using nutrient agar and glucose yeast extract agar respectively.

\section{Sensory evaluation}

All of the milk drink samples were evaluated for appearance/colour, flavour, body and mouthfeel and overall acceptability by a semitrained panel of eight judges from the department using a nine point hedonic scale with scores ranging from liked extremely (9) to disliked extremely (1) (Meilgaard et al., 1999).

The overall acceptability scores were calculated by taking mean of all the three attributes for each sample.

\section{Statistical analysis}

The data collected from the standardization and storage studies were subjected to the analysis of variance (Snedecor and Cochran, 1968), and factorial experiment in CRD (Critical Randomized Design) using CPCS1 software developed by the Department of Mathematics, Statistics and Physics, Punjab Agricultural University, Ludhiana, Punjab. 


\section{Results and Discussion}

\section{Proximate composition of milk and mango pulp}

The data pertaining to the various chemical characteristics of whey and mango pulp are presented in Table 1. It clearly indicates that whey and mango pulp were as expected rich in SNF and ascorbic acid respectively. Mango pulp was found better in TSS, total and reducing sugars contents whereas whey was better in protein, SNF, fat and total solids. The results obtained with respect to chemical characteristic are in agreement with the earlier studies.

Effect of ambient storage $\left(25 \pm 1^{\circ} \mathrm{C}\right)$ on physicochemical characteristics of sterilized mango-milk beverage

The changes in beverage stored under ambient temperature $\left(25 \pm 1^{\circ} \mathrm{C}\right)$ were evaluated for physicochemical, sensory and microbial parameters for 60 days of storage. The study showed that the physicochemical parameters were affected significantly $(\mathrm{p}<0.05)$ during 60 days of storage (Table 2).

The individual effect of storage days $(0,15$, 30,45 and 60 days) on total solids, TSS, titratable acidity, $\mathrm{pH}$, reducing sugars, ascorbic acid, viscosity, antioxidant activity and HMF generation of sterilized mango-milk beverage was found significant. Also individual effect of type of selected sterilized mango-milk beverage was found significant for drink characteristics such as total solids, TSS, titratable acidity, $\mathrm{pH}$, reducing sugars, ascorbic acid, viscosity, antioxidant activity and HMF generation. While combined effect of storage days and drink type in sterilized mango-milk beverage on total solids, TSS, titratable acidity, $\mathrm{pH}$, reducing sugars, ascorbic acid, viscosity, antioxidant activity and HMF generation was found non- significant. In the sterilized experimental beverage stored at room temperature $\left(25 \pm 1^{\circ} \mathrm{C}\right)$, the total solids content reduced significantly $(\mathrm{p}<0.05)$ from 12.61 to 11.39 and 15.46 to $14.59, \mathrm{pH}$ values from 6.60 to 5.80 and 6.40 to 5.90 for control and experimental beverage, respectively after 60 days of storage. The total soluble solids (TSS) showed an overall increase from 11.63 to 12.54 and 12.66 to 13.84 , titratable acidity (per cent lactic acid) from 0.125 to 0.139 per cent and 0.144 to 0.151 per cent for control and experimental beverage, respectively. The reducing sugar content was decreased significantly $(\mathrm{p}<0.05)$ from 4.37 to 3.34 per cent and 4.42 to 4.77 per cent, the ascorbic acid content from 1.26 to $0.60 \mathrm{mg} / 100 \mathrm{~g}$ and 1.62 to $0.77 \mathrm{mg} / 100 \mathrm{~g}$, viscosity of the drinks decreased significantly $(\mathrm{p}<0.05)$ from 1.56 to $1.38 \mathrm{cP}$ and 1.67 to $1.51 \mathrm{cP}$ while the antioxidant activity (per cent inhibition of $\mathrm{DPPH}$ ) from 30.48 to 25.25 and 40.93 to 34.11 and HMF concentration from 136.70 to 126.99 and 142.46 to $132.30 \mu \mathrm{g} / 100 \mathrm{~g}$ for control and experimental beverage, respectively. According to DeMan (1999) ascorbic acid is the least stable of all the vitamins and is easily destroyed during processing and storage. A noticeable decline in the ascorbic acid content of muskmelon RTS beverage during six months storage was also noticed by Teotia et al., (1997). Njoku et al., (2011) found significant decrease in ascorbic acid in different fruit juices (orange, lemon, lime and grapes) packaged in plastic bottles and stored at room temperature. Similar results for physicochemical changes were earlier observed by Kumar and Manimegalai (2005) in whey-based papaya juice blended ready to serve beverage stored at refrigerated temperature for three months. Taherzadeh et al., (2000) found that HMF was used up and converted by the yeast during storage of beer, and the main conversion product was 5-hydroxymethylfurfuryl alcohol (HMF alcohol). 
Table.1 Proximate composition of milk and mango pulp

\begin{tabular}{|l|c|c|}
\hline Component & Milk & Mango pulp \\
\hline Moisture (\%) & 88.67 & 78.36 \\
\hline Total solids (\%) & 11.70 & 21.64 \\
\hline Fat (\%) & 0.49 & 0.50 \\
\hline Protein (\%) & 3.22 & 0.70 \\
\hline Ash $(\%)$ & 0.75 & 0.54 \\
\hline Total soluble solids ( $\left.{ }^{\circ} \mathrm{B}\right)$ & 12.0 & 18.00 \\
\hline Titratable acidity (\% lactic acid) & 0.12 & $0.13 *$ \\
\hline pH & 6.57 & 4.80 \\
\hline
\end{tabular}

Mean of six replicates, *Significant at $\mathrm{p}<0.05$

Table.2 Effect of ambient $\left(25.0 \pm 0.1{ }^{\circ} \mathrm{C}\right)$ storage on the physicochemical characteristics of sterilized mango-milk beverage

\begin{tabular}{|c|c|c|c|c|c|c|c|c|}
\hline \multirow[t]{2}{*}{ Type of drink } & \multicolumn{5}{|c|}{ Storage (days) } & \multirow{2}{*}{$\begin{array}{c}\text { Storage } \\
\text { (S) }\end{array}$} & \multirow{2}{*}{$\begin{array}{c}\text { Drink } \\
\text { type }\end{array}$} & \multirow[t]{2}{*}{ S X D } \\
\hline & $\mathbf{0}$ & 15 & 30 & 45 & 60 & & & \\
\hline \multicolumn{9}{|l|}{ Total solids (\%) } \\
\hline Control & 12.61 & 12.29 & 12.03 & 11.54 & 11.39 & & & \\
\hline Milk beverage & 15.46 & 14.93 & 14.83 & 14.63 & 14.59 & $63.771 *$ & $1.072 *$ & NS \\
\hline \multicolumn{9}{|l|}{ TSS $\left({ }^{\circ} \mathbf{B}\right)$} \\
\hline Control & 11.63 & 11.58 & 11.81 & 12.24 & 12.54 & & & \\
\hline Milk beverage & 12.66 & 12.71 & 12.83 & 13.51 & 13.84 & $9.9646 *$ & $1.350 *$ & NS \\
\hline \multicolumn{9}{|c|}{ Titratable acidity (\% lactic acid) } \\
\hline Control & 0.125 & 0.126 & 0.127 & 0.128 & 0.139 & & & \\
\hline Milk beverage & 0.144 & 0.145 & 0.147 & 0.147 & 0.151 & $0.002 *$ & $0.0001 *$ & NS \\
\hline \multicolumn{9}{|l|}{ pH } \\
\hline Control & 6.60 & 6.60 & 6.50 & 6.30 & 5.80 & & & \\
\hline Milk beverage & 6.40 & 6.30 & 6.30 & 6.10 & 5.90 & $0.3738^{*}$ & $0.6882 *$ & NS \\
\hline \multicolumn{9}{|c|}{ Reducing sugars (\%) } \\
\hline Control & 4.37 & 4.35 & 4.35 & 3.64 & 3.34 & & & \\
\hline Milk beverage & 4.42 & 4.31 & 4.36 & 4.17 & 3.77 & $0.288^{*}$ & $0.811^{*}$ & NS \\
\hline \multicolumn{9}{|c|}{ Ascorbic acid (mg/100g) } \\
\hline Control & 1.26 & 1.28 & 0.86 & 0.87 & 0.60 & & & \\
\hline Milk beverage & 1.62 & 1.45 & 0.93 & 0.92 & 0.77 & $0.204 *$ & $0.649 *$ & NS \\
\hline \multicolumn{9}{|l|}{ Viscosity (cP) } \\
\hline Control & 1.56 & 1.53 & 1.46 & 1.38 & 1.38 & & & \\
\hline Milk beverage & 1.67 & 1.64 & 1.59 & 1.52 & 1.51 & $0.111^{*}$ & $0.035^{*}$ & NS \\
\hline \multicolumn{9}{|c|}{ Antioxidant activity (\% inhibition of DPPH) } \\
\hline Control & 30.48 & 30.46 & 28.75 & 26.78 & 25.25 & & & \\
\hline Milk beverage & 40.93 & 40.01 & 38.85 & 38.63 & 34.11 & $774.284^{*}$ & $34.738^{*}$ & NS \\
\hline \multicolumn{9}{|l|}{ HMF $(\mu \mathrm{g} / 100 \mathrm{~g})$} \\
\hline Control & 136.70 & 136.89 & 132.04 & 129.40 & 126.99 & & & \\
\hline Milk beverage & 142.46 & 138.46 & 139.76 & 138.46 & 132.30 & $260.012 *$ & $87.265^{*}$ & NS \\
\hline
\end{tabular}

Mean of six replicates, *Significant at $\mathrm{p}<0.05$; NS: Non Significant 
Table.3 Effect of ambient $\left(25.0 \pm 0.1^{\circ} \mathrm{C}\right)$ storage on the sensory scores of sterilized mango-milk beverage

\begin{tabular}{|c|c|c|c|c|c|c|c|c|c|}
\hline \multirow[t]{2}{*}{ Type of drink } & \multicolumn{6}{|c|}{ Storage (days) } & \multirow{2}{*}{$\begin{array}{l}\text { Storage } \\
\text { (S) }\end{array}$} & \multirow{2}{*}{$\begin{array}{c}\text { Drink } \\
\text { type }\end{array}$} & \multirow[t]{2}{*}{ S X D } \\
\hline & $\mathbf{0}$ & 15 & 30 & 45 & 60 & 75 & & & \\
\hline \multicolumn{10}{|c|}{ Appearance/ colour } \\
\hline Control & 8.56 & 8.46 & 8.04 & 7.81 & 7.46 & 7.32 & & & \\
\hline Milk beverage & 8.36 & 8.26 & 7.88 & 7.51 & 7.31 & 7.13 & $4.1377^{*}$ & $0.9798^{*}$ & NS \\
\hline \multicolumn{10}{|l|}{ Flavour } \\
\hline Control & 8.44 & 7.93 & 7.28 & 6.48 & 6.15 & 5.58 & & & \\
\hline Milk beverage & 8.18 & 7.34 & 6.79 & 6.36 & 6.09 & 5.53 & $16.5871 *$ & $1.6414^{*}$ & NS \\
\hline \multicolumn{10}{|c|}{ Body and mouth feel } \\
\hline Control & 8.53 & 8.46 & 8.04 & 7.81 & 7.46 & 7.32 & & & \\
\hline Milk beverage & 8.38 & 8.28 & 7.85 & 7.59 & 7.37 & 7.14 & $4.1254^{*}$ & $0.8903^{*}$ & NS \\
\hline \multicolumn{10}{|c|}{ Overall acceptability } \\
\hline Control & 8.51 & 8.29 & 7.79 & 7.37 & 7.03 & 6.74 & & & \\
\hline Milk beverage & 8.31 & 7.96 & 7.51 & 7.13 & 6.91 & 6.59 & $7.3031 *$ & $1.1489 *$ & NS \\
\hline
\end{tabular}

Mean of six replicates, *Significant at $\mathrm{p}<0.05$; NS: Non Significant

Fig.1 Process flow chart for the preparation of mango flavored milk beverage

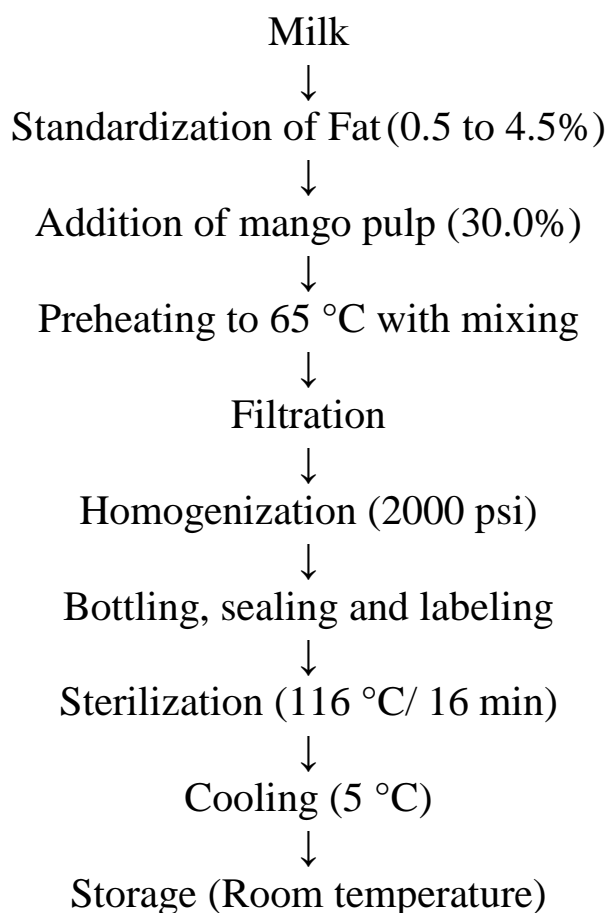

The storage of soybean beverages caused a significant $(\mathrm{p}<0.05)$ decrease of antioxidant capacity, soluble phenolics, and isoflavone contents after 9 months at room temperature.
When soybeans used for beverage production were stored for up to 6 months in silos, the resulting products were not affected. However, a decrease of malonyl and a 
proportional increase of free glucosidic forms of isoflavones were observed after storage of both the raw material and the experimental beverages (Rau et al., 2010). Similarly, a significant $(\mathrm{p}<0.05)$ decrease in antioxidant activity of Centellaasiatica (gotu kola) drinks packaged in polypropylene and HDPE bottles was also noticed by Siah et al., (2011).

The pasteurized low calorie mango flavoured milk drinks prepared by replacing sugar with sucralose and adding 10 per cent mango pulp in milk of low fat content ( 0.5 per cent $)$ recorded a significant $(p<0.01)$ loss in the viscosity, ascorbic acid and reducing sugar content during the storage period of 10 days at $5.0 \pm 0.1^{\circ} \mathrm{C}$. However, the titratable acidity increased to undesirable levels after 8 days making the drinks unacceptable (Mittal and Bajwa, 2013).

\section{Effect of ambient storage $\left(25 \pm 1^{\circ} \mathrm{C}\right)$ on the sensory scores of sterilized mango-milk beverage}

The effect of storage on sensory scores of sterilized mango-milk beverage is presented in Table 3. The scores of appearance/color decreased significantly $(\mathrm{p}<0.05)$ from 8.56 to 7.52 and 8.36 to 7.13 , flavour from 8.44 to 5.58 and 8.18 to 5.53 , body and mouth feel from 8.53 to 7.32 and 8.38 to 7.14 and the overall acceptability from 8.51 to 6.74 and 8.31 to 6.59 for control and experimental beverage, respectively after the storage of 75 days.

The individual effect of storage days $(0,15$, 30, 45, 60 and 75 days) on appearance, flavor, body and mouthfeel and overall acceptability of sterilized mango-milk beverage was found significant. Also individual effect of type of selected sterilized mango-milk beverage was found significant for sensory characteristics such as appearance, flavor, body and mouthfeel and overall acceptability. While combined effect of storage days and drink type on appearance, flavor, body and mouthfeel and overall acceptability of sterilized mango-milk beverage was found non-significant.

The beverage remained acceptable to sensory panel up to 60 days of storage. The fall in scores was due to the development of slight burnt/cooked aftertaste in the drinks as perceived by some of the sensory panelists. A similar trend for sensory scores in stored milk beverage was also found by Cano-Ruiz and Richter (1998). Heat treatment causes milk fat globule membrane proteins and whey proteins to unfold and sulfhydryl (-SH-) groups are exposed to the outer surfaces which produce cooked flavors, often attributed to changes in the sulfhydryl and disulfide content of the protein fraction of milk beverages (Swaisgood et al., 1987). Shekilango et al., (1997) also found that the characteristics like appearance, colour, flavor, taste and overall acceptability of sensory evaluation were in decreasing trend in a storage study of whey based mango beverage.

Effect of ambient storage $\left(25 \pm 1^{\circ} \mathrm{C}\right)$ on the microbial counts of sterilized mango-milk beverage

In sterilized experimental beverages, standard plate count, yeast and mold count and spore formers were not detectable throughout the storage of 75 days. This showed that the sterilized beverages were microbiologically stable but due to the deterioration in organoleptic quality, these were rejected after 60 days of storage.

Above study has revealed satisfactorily good quality sterilized functional beverage with anti-oxidative value prepared by using a 70:30 blend of milk and mango pulp with 6 percent sugar with a shelf life of 60 days at $25^{\circ} \mathrm{C} \pm 1^{\circ} \mathrm{C}$. Based on consumer demand and 
the potential health benefits, we believe that new functional beverages will be launched. The keys to design new functional beverages could be: addition of a component to provide health benefits; removal of a component by technological or biotechnological means so that the food provides benefits not otherwise available; replacement of a component by an alternative component with favorable properties; modification of a component by enzymatic, chemical, or technological means to provide a benefit or a combination of any of the above The future of functional beverages depends on the unequivocal demonstration of their efficacy in promoting health. Thus, a joint venture between food producers and researchers is advisable, as a tool to provide scientific evidence of many health claims, as well as a way to find successful strategies to improve the appeal of functional beverages.

\section{References}

Ames, J.M. 2009. Dietary Maillard reaction products: implications for human health and disease. Czech Journal of Food Science. 27: S66-S69.

AOAC. (2000), Official methods of Analysis. Association of Official Analytical Chemists, Guthersburg, Maryland, USA. $17^{\text {th }}$ edition.

Cano-ruiz, M.E. and Richter, R.L. 1998. Changes in physicochemical properties of retort-sterilized dairy beverages during storage. Journal of Dairy Science. 81: 2116-2123.

DeMan, J.M. (1999), Principles of Food Chemistry. AVI Publishers, New York.

Franzke, C. and Iwainsky, H. 1954. Antioxidant capacity of melanoidin. DeutLebensm-Rundsch. 50: 251-254.

Gothwal, P.P. and Bhavadasan, M.K. 1992. Studies on the browning characteristics in dairy products. Indian Journal of Dairy Science. 45: 146-151.
Kumar, S.R. and Manimegalai, G. 2005. Studies on storage stability of whey based papaya juice lended RTS beverage. Journal of Food Science and Technology. 42: 185-188.

Lingnert, H. and Hall, G. 1986. Formation of antioxidative Maillard reaction products during food processing. In: Fujimaki M, Namiki M, Kato E (ed) Amino-carbonyl reactions in food and biological systems, Tokyo: Elsevier, pp. 273-279.

Meilgaard, M., Civille, G.V. and Carr, B.T. 1999. Sensory evaluation techniques. CRC Press, Bocan Raton.

Mittal, S. and Bajwa, U. 2011. Effect of fat and sugar substitution on the quality characteristics of low calorie milk drinks. The Journal of Food Science and Technology. 10: 216-219.

Mittal, S. and Bajwa, U. 2013. Quality characteristics of no added sugar ready to drink milk supplemented with mango pulp. Journal of Food Science and Technology. DOI 10.1007/s13197-0131184-7a.

Morales, F.J., Romero, C. and Jimenez-Perez, S. $\quad 1997 . \quad$ Chromatographic determination of bound Hydroxymethylfurfural as an index of milk protein glycosylation. Journal of Agricultural and Food Chemistry. 45: 1570-1573.

Njoku, P.C., Ayuk, A.A. and Okoye, C.V. 2011. Temperature Effects on Vitamin C Content in Citrus Fruits. Pakistan Journal of Nutrition. 10: 1168-1169.

Ozer, B.H. and Kirmaci, H.A. 2009. Functional milks and milk beverages. International Journal of Dairy Technology. 63: 1-6

Pal, R.K. 1998. Ripening and rheological properties of mango as influenced by ethereal and carbide. Journal of Food Science and Technology. 35: 358-360.

Pravst, I. 2012. Functional Foods in Europe: A Focus on Health Claims, Scientific, 
Health and Social Aspects of the Food Industry. DOI: 10.5772/31057.

Ranganna, S. 1994. Handbook of analysis and quality control for fruits and vegetables products. Tata McGraw Hill Publishing Company Limited, New Delhi.

Rao, M.S., Chawla, S.P., Chander, R. and Sharma, A. 2011. Antioxidant potential of Maillard reaction products formed by irradiation of Chitosan glucose solution. Carbohydrate Polymers. 83: 714-719.

Shekilango, S.A., Jelen. P. and Bagdan, G.C. 1997. Production of whey-banana experimental beverages from acid whey and over ripe bananas. Milchwissenschaft. 52: 209-212.

Siah, H., Faridah, M.Z., Rahimah, S., Mohd Tahir, and Mohd Zain, D. 2011. Effects of packaging materials and storage on total phenolic content and antioxidant activity of Centella asiatica drinks. Journal of Tropical Agriculture and Food Science. 39: 340-355.

Snedecor, G.W. and Cochran, W.G. 1968. Statistical methods. Oxford and IBH Publishing Company, New Delhi.

Swaisgood, H.E., Janolino, V.G. and Skudder, P.J. 1987. Continuous treatment of ultrahigh temperature sterilized milk using immobilized sulfhydryl oxidase. Methods of Enzymology. 136: academic press London pp. 423-431.

Taherzadeh, M.J., Gustafsson, L., Niklasson, C. and Liden, G. 2000. Physiological effects of 5- hydroxymethylfurfural on Saccharomyces cerevisiae. Applied Microbiology and Biotechnology. 53: 701-708.

Teotia, M.S., Kaur, S. and Berry, S.K. 1997. Utilization of muskmelon ready to serve experimental beverage from enzyme clarified juice. Indian Food Packer. 51: 11-17.

Tepe, B., Sokmen, M., Akpulat, H.A. and Sokmen, A. 2005. In vitro antioxidant activities of the methanol extracts of four Helichrysum species from Turkey. Food Chemistry. 90: 685-689.

Yadav, R.B., Yadav, B.S. and Kalia, N. 2010. Development and storage studies on whey-based banana herbal (Mentha arvensis) beverage. American Journal of Food Technology. 5: 121-129.

\section{How to cite this article:}

Preeti Shukla, U. Bajwa and Suresh Bhise. 2018. Effect of Storage on Quality Characteristics of Sterilized Mango Based Dairy Beverage. Int.J.Curr.Microbiol.App.Sci. 7(04): 1173-1182. doi: https://doi.org/10.20546/ijcmas.2018.704.130 